\title{
The clinical value, regulatory mechanisms, and gene network of the cancer-testis gene STK31 in pancreatic cancer
}

\author{
Kai Zhang ${ }^{1,2, *}$, Zipeng Lu ${ }^{1,2, *}$, Yi Zhu ${ }^{1,2}$, Lei Tian ${ }^{1,2}$, Jingjing Zhang ${ }^{1,2}$, Chunhua $\mathrm{Xi}^{1,2}$, \\ Wentao Gao ${ }^{1,2}$, Kuirong Jiang ${ }^{1,2}$ and Yi Miao ${ }^{1,2}$ \\ ${ }^{1}$ Pancreatic Center \& Department of General Surgery, The First Affiliated Hospital of Nanjing Medical University, Nanjing \\ 210029, Jiangsu, China \\ ${ }^{2}$ Pancreas Institute of Nanjing Medical University, Nanjing 210029, Jiangsu, China \\ *These authors have contributed equally to this work \\ Correspondence to: Yi Miao, email: miaoyi@njmu.edu.cn
}

Keywords: cancer-testis gene, pancreatic cancer, STK31

Received: December 02, $2016 \quad$ Accepted: March 17, $2017 \quad$ Published: April 04, 2017

Copyright: Zhang et al. This is an open-access article distributed under the terms of the Creative Commons Attribution License (CC-BY), which permits unrestricted use, distribution, and reproduction in any medium, provided the original author and source are credited.

\section{ABSTRACT}

We aimed to identify STK31 as a cancer-testis (CT) gene and to explore its potential clinical value, regulatory mechanisms, and gene network in pancreatic cancer (PC). Gene expression data were generated from normal organ samples and pancreatic cancer samples from three public databases. STK31 expression patterns in normal and PC tissues were identified, and we explored its regulatory mechanisms. Gene ontology (GO) and pathway analyses of STK31-related genes were performed and an STK31 protein-protein interaction (PPI) network was constructed. STK31 was confirmed as a CT gene in PC and its expression was significantly higher in patients with new neoplasm compared with patients without new neoplasm $(P=0.046)$ and in more advanced pathologic stages than in earlier stages $(P=0.002)$; methylation level correlated negatively with STK31 expression. In total, 757 STK31-related genes were identified, and were significantly enriched in terms of polymorphisms and alternative splicings. The PPI network predicted that STK31 was physically associated with the PIWI (originally P-element Induced WImpy testis in Drosophila) and Tudor families.

\section{INTRODUCTION}

$\mathrm{PC}$ is a highly malignant digestive tract disease with difficult early diagnosis and treatment. In almost $90 \%$ of patients, it originates from the epithelial gland ductal carcinoma $[1,2]$. In the US, the five-year survival rate of $\mathrm{PC}$ remains as low as 6\% [3]. The low survival rate is attributed to several factors, perhaps the most important of which is the late stage and metastasis when most patients are diagnosed [1-3]. Unfortunately, most patients are asymptomatic until it develops to an advanced stage.

The most well-established risk factor for $\mathrm{PC}$ is cigarette smoking, [4]. Chronic pancreatitis [5], diabetes persisting more than 20 years [6], high body mass index (BMI), and centralized fat distribution [7]. Previous studies have suggested four major driver genes of PC: KRAS (Kras proto-oncogene, GTPase), CDKN2A (cyclindependent kinase inhibitor 2A), TP53 (tumor protein p53), and SMAD4 (SMAD family member 4). These four genes are referred to as mutation driver genes of PC $[3,8]$. However, these genes can only explain parts of pancreatic tumorigenesis; these genetic mutations are not present in many other patients with PC. Therefore, epigenetic drivers were put forward. Epigenetic drivers mean that epigenetic changes could alter gene expression, leading to the occurrence of tumors. They are now acknowledged as a universal feature of tumorigenesis [8]. Cancer-testis (CT) genes, whose expression is restricted to germ cells and is often reactivated and aberrantly expressed in cancers, are a group of epigenetic driver genes [9, 10]. Recently, patient-derived xenograft models of pancreatic ductal adenocarcinoma (PDAC) showed that JQ1, an inhibitor of CT genes in the bromodomain and extraterminal (BET) protein family (BRDT), suppresses PDAC development by inhibiting both MYC (v-myc avian myelocytomatosis viral oncogene homolog) activity and inflammatory signals 
[11]. This provided new insight into the molecular targets of PC. These findings all suggested that CT genes might play an important role in molecular targeted therapy of PC.

Recently, we found that STK31 (serine/threonine kinase 31, also known as TDRD8) might be a novel CT gene in PC [10]. As a Tudor family member, STK31 contains an STK domain and a Tudor domain, and participates in cell cycle regulation [12]. In mice, the homologous protein of STK31 is restricted to germ cells $[13,14]$ and is highly expressed in spermatogonia meiosis $[13,15,16]$. Moreover, STK31 has been detected in colorectal cancer and is activated by demethylation [14]. In Caco2 and SW1116 colorectal cancer cells, STK31 knockdown enhanced cell differentiation capacity, indicating that STK31 maintains low differentiation in colorectal cancer cells $[12,14,16]$.

In the present study, we deciphered the expression pattern of STK31 and attempted to confirm whether it will be a good biomarker aiding clinical diagnosis and prognosis of PC. We also attempted to uncover the regulatory mechanisms and gene network of STK31 in PC.

\section{RESULTS}

\section{Tissue expression patterns and role of $S T K 31$ in PC}

To determine whether STK31 could be assigned to the CT genes expressed in PC, we first evaluated its expression pattern in normal human tissues including pancreas using transcriptomic data deposited in the Genotype-Tissue Expression Project (GTEx). STK31 was mainly expressed in the testis (Figure 1A). The Human Protein Atlas (HPA) result was generally consistent with the GTEx data, showing that STK31 was only expressed in the testis at both RNA and protein level (Figure 1B \& 1D). Next, we evaluated STK31 expression in PC specimens through bioinformatics analysis of RNA sequencing (RNA-seq) of The Cancer Genome Atlas (TCGA) PAAD data (178 PC samples), which indicated that STK31 was elevated in about $85 \%$ of patients with PC (Figure 1C), which was also supported by the HPA (Figure 1E). These results confirm that $S T K 31$ is a CT gene in PC.
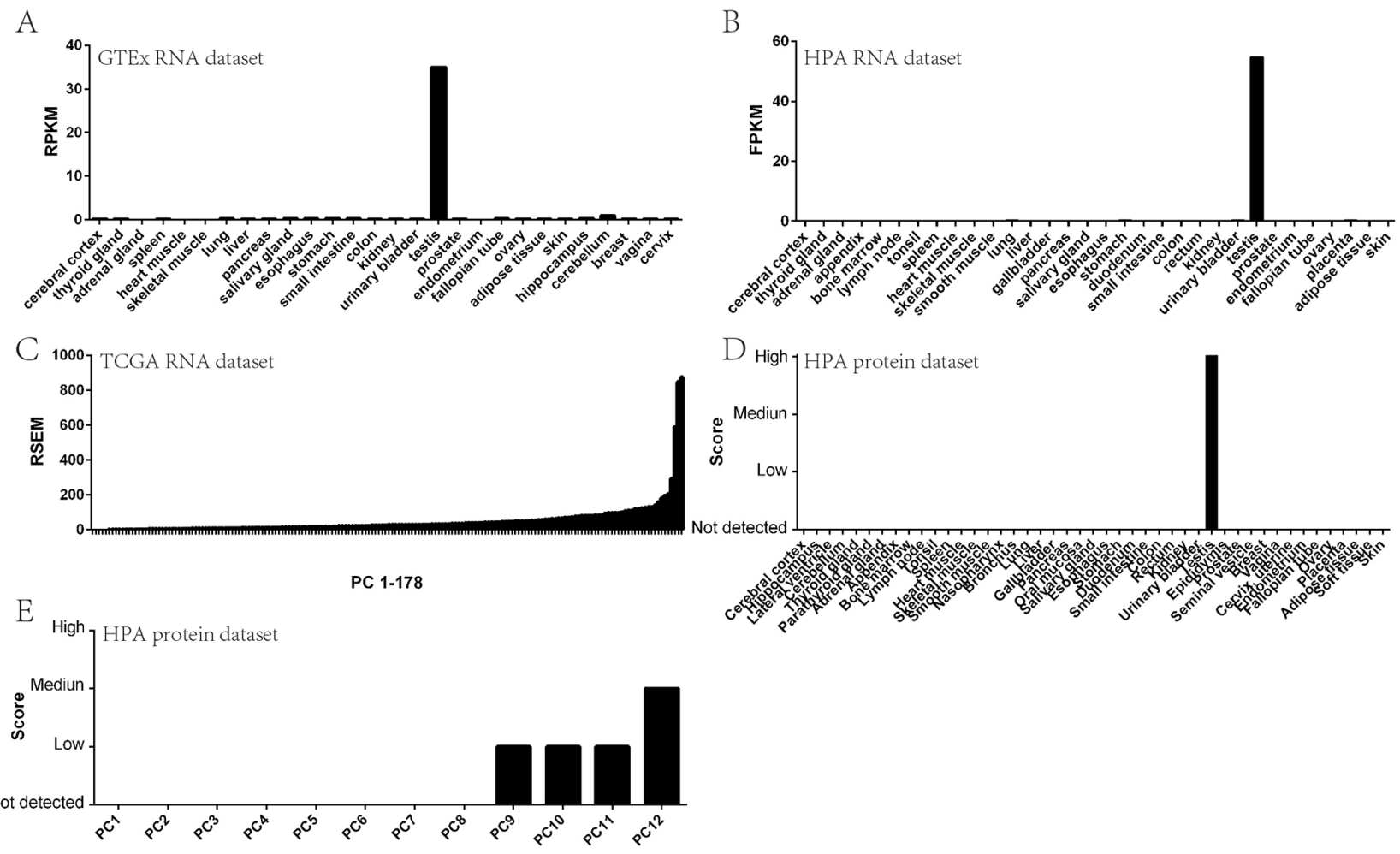

Figure 1: STK31 tissue expression pattern. STK31 RNA expression in normal tissues from GTEx (A) and HPA (B); STK31 RNA expression in pancreatic cancer tissues from TCGA (C); STK31 protein expression in normal tissues from HPA (D); STK31 protein expression in pancreatic cancer tissues from HPA (E). RPKM: Reads Per Kilobases per Millionreads; FPKM: Fragments Per Kilobase Million; 
Interestingly, STK31 expression was significantly higher in patients with new neoplasm compared with patients without new neoplasm $(P=0.046$, Figure 2A). We also found that patients at more advanced pathologic stages tended to express $S T K 31(P=0.002$, Figure 2B).
To explore the association of STK31 expression and the survival time of patients with PC, Kaplan-Meier survival curves based on STK31 expression were constructed, showing that patients who expressed STK31 had poorer survival (log-rank: $P=0.0009$, Figure 3 ).

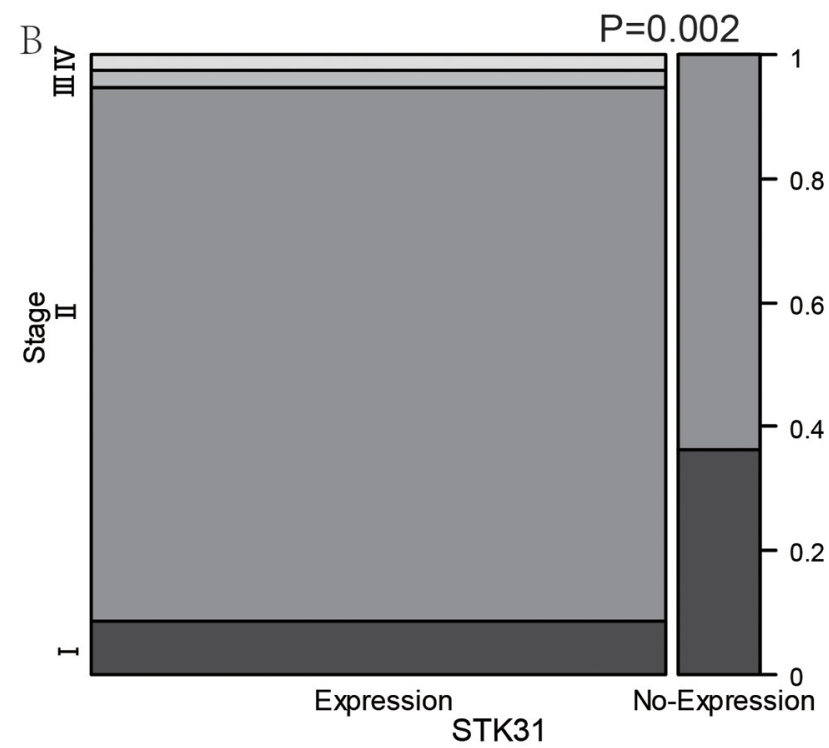

Figure 2: The association between $S T K 31$ expression and clinical features of pancreatic cancer. $S T K 31$ expression was significantly higher in patients with new neoplasm compared patients without new neoplasm (A) and in more advanced pathologic stages than in earlier stages (B).

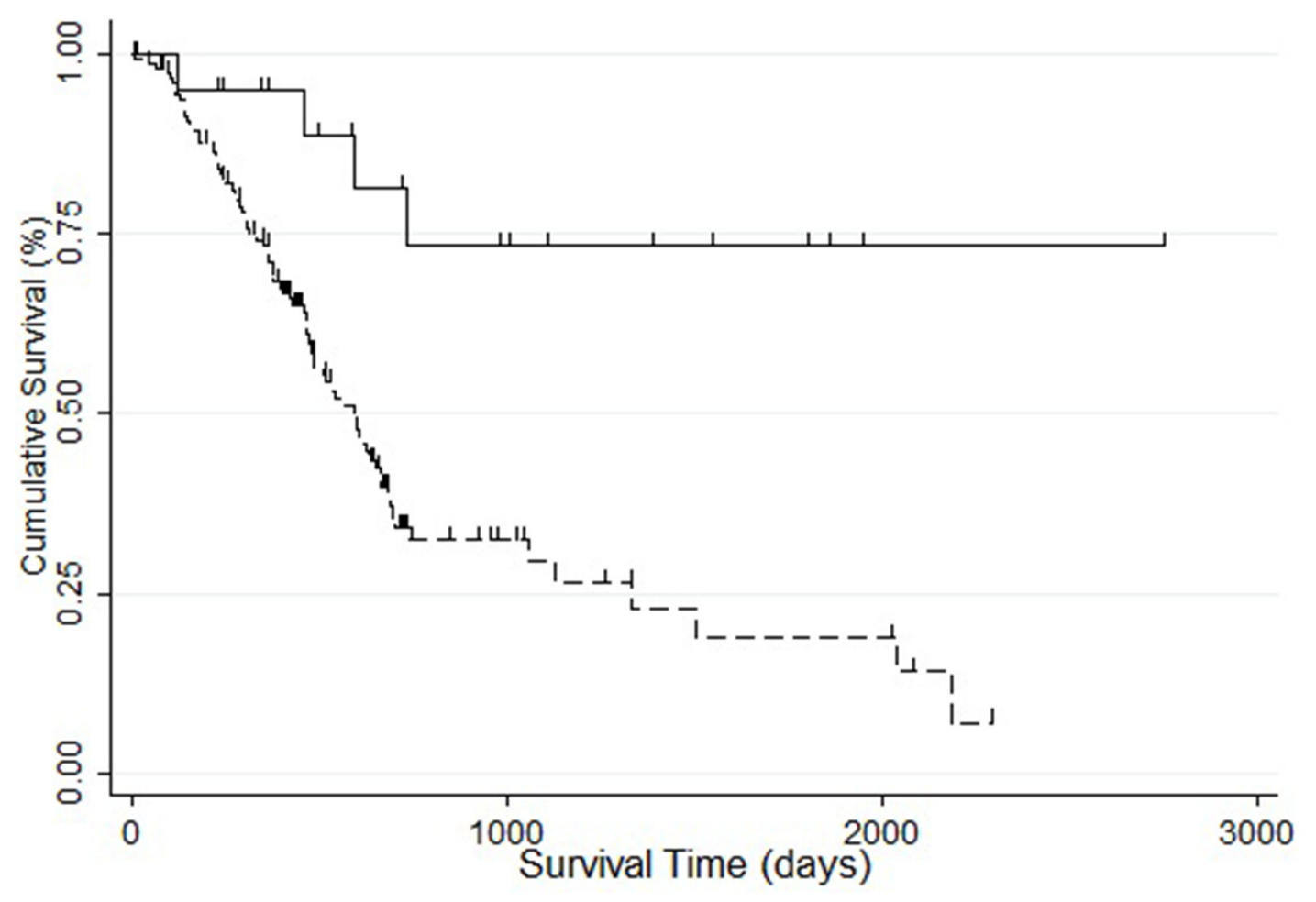

Figure 3: The association between STK31 expression and survival of patients with pancreatic cancer. Patients with $S T K 31$ expression (RSEM>5, dotted line) had poorer survival than patients without $S T K 31$ expression (RSEM $\leq 5$, solid line). 


\section{The relationship between methylation, mutation,} and $S T K 31$ expression

In TCGA, almost one-fifth of patients with PC did not harbor the four major mutation driver genes in PC
(KRAS, CDKN2A, TP53, SMAD4) (Figure 4A). Only 2\% of patients carried STK31 mutations. These results suggest another driving mode, such as epigenetic drivers, in PC. Further analysis showed that there was almost no histone modification in the STK31 promoter region (2 kb upstream

A

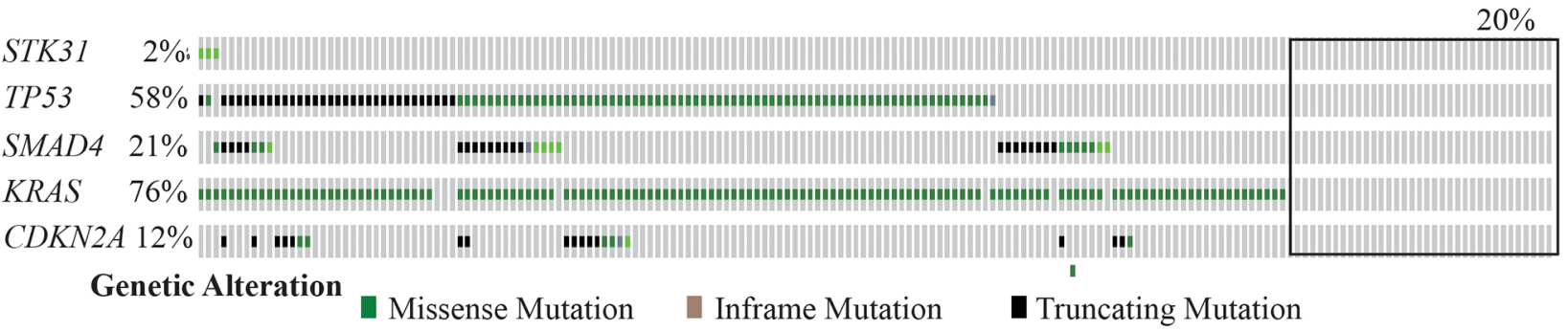

B

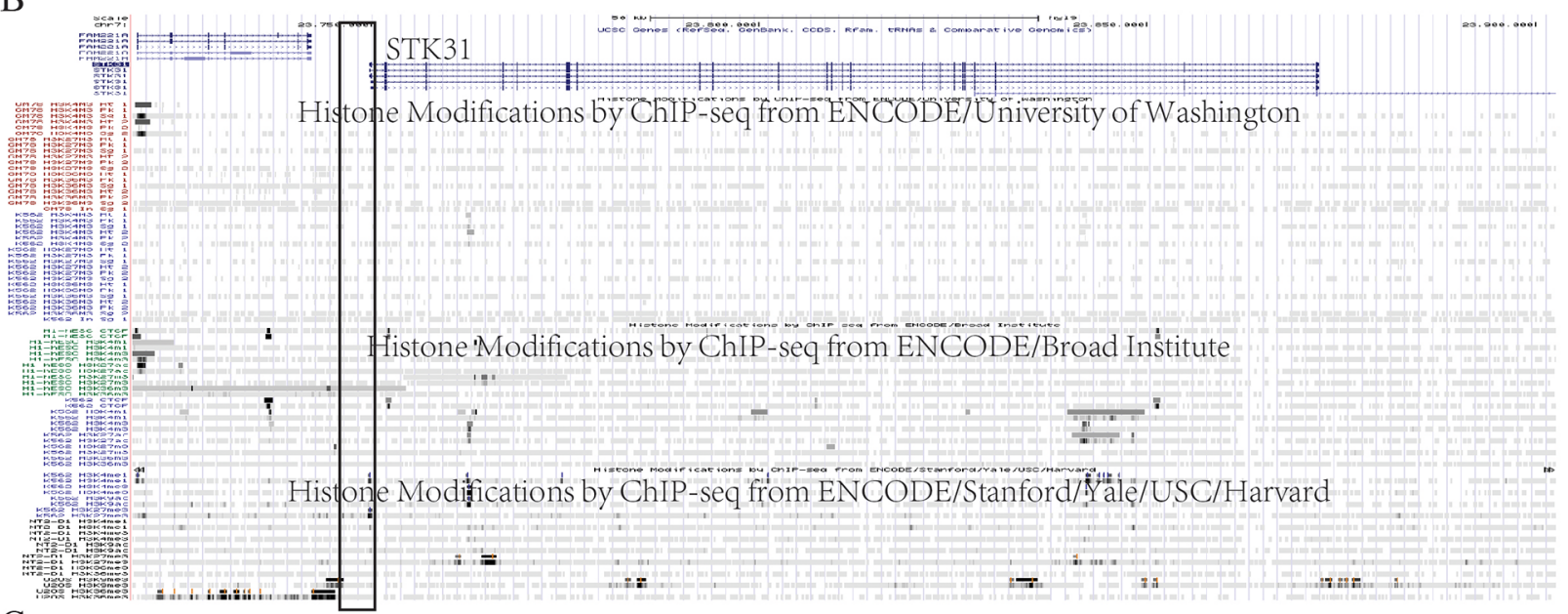

$\mathrm{C}$

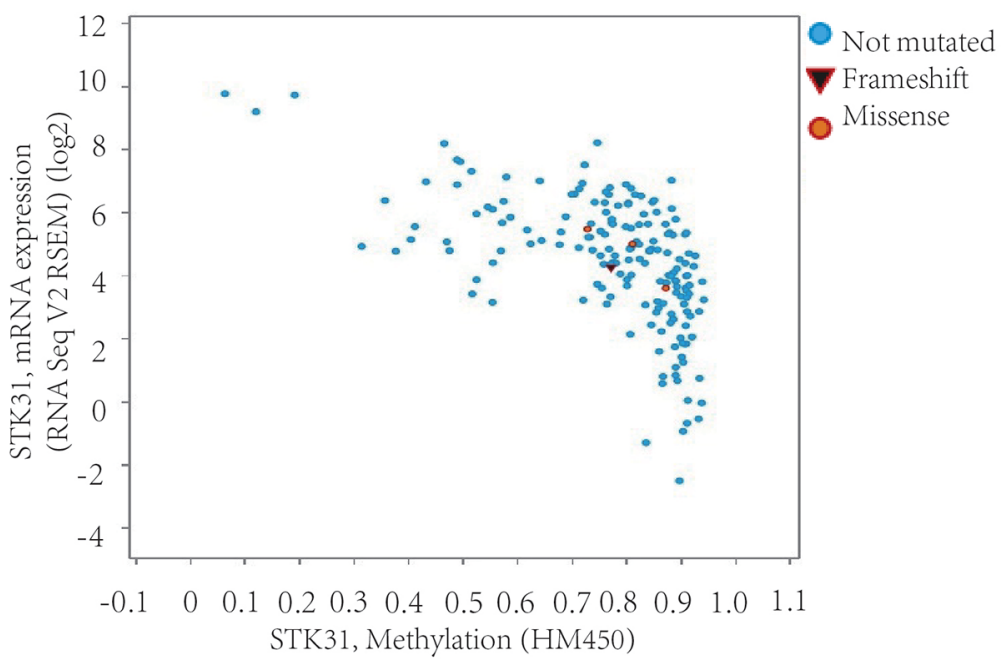

Figure 4: The relationship between methylation, mutation, and STK31 expression. (A) Only 2\% of patients with pancreatic cancer carried STK31 mutations; almost one-third of patients with pancreatic cancer (black rectangle) did not carry the four major mutation driver genes (KRAS, CDKN2A, TP53, SMAD4). (B) There was almost no histone modification in the STK31 promoter region (2 kb upstream of $S T K 31)$ ). (C) Methylation levels (2 kb upstream of STK31) were negatively correlated with STK31 expression. 
Table 1: GO and pathway enrichment analysis of STK31-related genes.

\begin{tabular}{|c|c|c|c|}
\hline Category & Term & Count & FDR P-val \\
\hline Keywords & Polymorphism & 487 & $3.10 \mathrm{E}-$ \\
\hline Keywords & Alternative splicing & 442 & $6.20 \mathrm{E}-06$ \\
\hline Keywords & Phosphoprotein & 343 & $6.50 \mathrm{E}-08$ \\
\hline Keywords & Membrane & 289 & $2.40 \mathrm{E}-02$ \\
\hline Keywords & Cytoplasm & 231 & $2.10 \mathrm{E}-06$ \\
\hline Keywords & Nucleotide-binding & 91 & $4.90 \mathrm{E}-$ \\
\hline Keywords & Transferase & 89 & $7.80 \mathrm{E}-04$ \\
\hline Keywords & Ubl conjugation & 87 & $4.30 \mathrm{E}-03$ \\
\hline Keywords & ATP-binding & 79 & $6.00 \mathrm{E}-$ \\
\hline Keywords & Cytoskeleton & 72 & $3.60 \mathrm{E}-$ \\
\hline Keywords & Cell cycle & 58 & $1.40 \mathrm{E}-$ \\
\hline Keywords & Developmental protein & 55 & $5.20 \mathrm{E}$ \\
\hline Keywords & Cell division & 46 & $1.80 \mathrm{E}$ \\
\hline Keywords & Cell junction & 44 & $1.40 \mathrm{E}-03$ \\
\hline Keywords & Kinase & 41 & $3.20 \mathrm{E}-$ \\
\hline Keywords & Mitosis & 39 & $2.30 \mathrm{E}-11$ \\
\hline Keywords & Apoptosis & 36 & $5.90 \mathrm{E}-$ \\
\hline Keywords & Chromosome & 32 & $3.30 \mathrm{E}-04$ \\
\hline Keywords & Glycosyltransferase & 25 & $9.70 \mathrm{E}$ \\
\hline Keywords & Centromere & 24 & $1.70 \mathrm{E}$ \\
\hline Keywords & SH3 domain & 23 & $2.40 \mathrm{E}-04$ \\
\hline Keywords & Microtubule & 23 & $6.80 \mathrm{E}-03$ \\
\hline Keywords & Kinetochore & 20 & $2.50 \mathrm{E}$ \\
\hline Keywords & Motor protein & 15 & $5.00 \mathrm{E}$ \\
\hline Keywords & Tight junction & 14 & $2.30 \mathrm{E}$ \\
\hline Keywords & Tyrosine protein kinase & 13 & $8.60 \mathrm{E}$ \\
\hline Keywords & Microsome & 13 & $2.60 \mathrm{E}$ \\
\hline Keywords & Chromosome partition & 10 & $4.40 \mathrm{E}$ \\
\hline Keywords & Epidermolysis bullosa & 7 & $2.20 \mathrm{E}$ \\
\hline Keywords & Basement membrane & 7 & $3.20 \mathrm{E}$ \\
\hline \multicolumn{4}{|l|}{ GO analysis } \\
\hline MF & Protein kinase binding & 32 & 4.90E-02 \\
\hline $\mathrm{CC}$ & Cytoplasm & 239 & $2.60 \mathrm{E}$ \\
\hline $\mathrm{CC}$ & Cytosol & 176 & $9.00 \mathrm{E}$ \\
\hline $\mathrm{CC}$ & Extracellular exosome & 150 & $9.90 \mathrm{E}-$ \\
\hline $\mathrm{CC}$ & Nucleoplasm & 129 & $1.00 \mathrm{E}-$ \\
\hline $\mathrm{CC}$ & Focal adhesion & 30 & $1.20 \mathrm{E}-02$ \\
\hline
\end{tabular}

(Continued) 


\begin{tabular}{|c|c|c|c|}
\hline Category & Term & Count & FDR P-value \\
\hline $\mathrm{CC}$ & Midbody & 21 & $1.30 \mathrm{E}-05$ \\
\hline $\mathrm{CC}$ & Cell-cell junction & 17 & $1.10 \mathrm{E}-02$ \\
\hline $\mathrm{CC}$ & Kinetochore & 16 & $1.20 \mathrm{E}-05$ \\
\hline $\mathrm{CC}$ & $\begin{array}{c}\text { Condensed chromosome } \\
\text { kinetochore }\end{array}$ & 16 & $1.50 \mathrm{E}-05$ \\
\hline $\mathrm{CC}$ & Bicellular tight junction & 16 & $9.60 \mathrm{E}-04$ \\
\hline $\mathrm{CC}$ & $\begin{array}{l}\text { Chromosome, centromeric } \\
\text { region }\end{array}$ & 13 & $2.50 \mathrm{E}-05$ \\
\hline $\mathrm{CC}$ & Spindle pole & 12 & $2.60 \mathrm{E}-02$ \\
\hline $\mathrm{CC}$ & Spindle microtubule & 10 & $1.40 \mathrm{E}-03$ \\
\hline $\mathrm{CC}$ & Brush border & 10 & $3.00 \mathrm{E}-03$ \\
\hline $\mathrm{CC}$ & Mitotic spindle & 8 & $1.60 \mathrm{E}-02$ \\
\hline $\mathrm{CC}$ & Desmosome & 7 & 7.00E-03 \\
\hline $\mathrm{CC}$ & Hemidesmosome & 5 & $4.50 \mathrm{E}-03$ \\
\hline BP & $\begin{array}{l}\text { Small GTPase-mediated } \\
\text { signal transduction }\end{array}$ & 49 & $1.50 \mathrm{E}-02$ \\
\hline BP & Apoptotic process & 41 & $4.00 \mathrm{E}-02$ \\
\hline BP & Cell division & 37 & $6.60 \mathrm{E}-06$ \\
\hline BP & Mitotic cell cycle & 36 & $5.90 \mathrm{E}-03$ \\
\hline BP & Mitotic nuclear division & 32 & $3.50 \mathrm{E}-06$ \\
\hline BP & Cell proliferation & 32 & $6.80 \mathrm{E}-03$ \\
\hline BP & Cell migration & 20 & $6.60 \mathrm{E}-03$ \\
\hline BP & Cell junction assembly & 19 & $1.30 \mathrm{E}-06$ \\
\hline BP & $\begin{array}{l}\text { Ephrin receptor signaling } \\
\text { pathway }\end{array}$ & 17 & 2.20E-04 \\
\hline BP & Chromosome segregation & 16 & 4.70E-05 \\
\hline BP & $\begin{array}{l}\text { Anterior/posterior pattern } \\
\text { specification }\end{array}$ & 13 & $1.60 \mathrm{E}-02$ \\
\hline BP & $\begin{array}{l}\text { Single organismal cell-cell } \\
\text { adhesion }\end{array}$ & 13 & $3.00 \mathrm{E}-02$ \\
\hline BP & Epidermis development & 12 & $3.50 \mathrm{E}-02$ \\
\hline BP & $\begin{array}{l}\text { Cell-cell junction } \\
\text { organization }\end{array}$ & 11 & $2.90 \mathrm{E}-02$ \\
\hline BP & $\begin{array}{l}\text { Bicellular tight junction } \\
\text { assembly }\end{array}$ & 10 & $6.10 \mathrm{E}-03$ \\
\hline BP & O-glycan processing & 10 & $3.60 \mathrm{E}-02$ \\
\hline BP & Hemidesmosome assembly & 7 & $9.10 \mathrm{E}-04$ \\
\hline BP & $\begin{array}{l}\text { Mitotic sister chromatid } \\
\text { segregation }\end{array}$ & 7 & 2.10E-02 \\
\hline BP & $\begin{array}{l}\text { Phosphatidylethanolamine } \\
\text { acyl-chain remodeling }\end{array}$ & 7 & $2.60 \mathrm{E}-02$ \\
\hline
\end{tabular}

(Continued) 


\begin{tabular}{|c|c|c|c|}
\hline Category & Term & Count & FDR P-value \\
\hline $\mathrm{BP}$ & Mitotic cytokinesis & 7 & 4.60E-02 \\
\hline $\mathrm{BP}$ & $\begin{array}{l}\text { Branching involved in } \\
\text { mammary gland duct } \\
\text { morphogenesis }\end{array}$ & 6 & $1.60 \mathrm{E}-02$ \\
\hline $\mathrm{BP}$ & $\begin{array}{l}\text { Negative regulation of } \\
\text { cellular glucuronidation }\end{array}$ & 5 & $2.20 \mathrm{E}-02$ \\
\hline $\mathrm{BP}$ & $\begin{array}{l}\text { Negative regulation of } \\
\text { glucuronosyltransferase } \\
\text { activity }\end{array}$ & 5 & $2.20 \mathrm{E}-02$ \\
\hline $\mathrm{BP}$ & $\begin{array}{l}\text { Negative regulation of fatty } \\
\text { acid metabolic process }\end{array}$ & 5 & $2.90 \mathrm{E}-02$ \\
\hline $\mathrm{BP}$ & Xenobiotic glucuronidation & 5 & $2.90 \mathrm{E}-02$ \\
\hline \multicolumn{4}{|l|}{ pathway } \\
\hline KEGG_PATHWAY & Tight junction & 16 & $6.80 \mathrm{E}-03$ \\
\hline KEGG_PATHWAY & Axon guidance & 15 & $2.30 \mathrm{E}-02$ \\
\hline KEGG_PATHWAY & Adherens junction & 12 & $7.40 \mathrm{E}-03$ \\
\hline KEGG_PATHWAY & $\begin{array}{c}\text { Glycosphingolipid } \\
\text { biosynthesis - lacto and } \\
\text { neolacto series }\end{array}$ & 7 & $3.00 \mathrm{E}-02$ \\
\hline
\end{tabular}

of the STK31) (http://genome.ucsc.edu/cgi-bin/hgGateway, Figure 4B). Interestingly, we found that methylation level (2 kb upstream of STK31) was negatively correlated with STK31 expression (Pearson $\mathrm{r}=-0.634$, Spearman $\mathrm{r}=-0.634$, http://www.cbioportal.org/index.do, Figure 4C).

\section{The STK31 gene network}

We analyzed the relationship between STK31 and 20,530 other genes. Seven hundred and fifty-seven genes were related with STK31 $\left(P<1 \times 10^{-6}\right)$, where STK31 was strongly associated with piwi-like RNA-mediated gene silencing 1 (PIWIL1) $\left(\mathrm{r}=0.50, P=5.56 \times 10^{-15}\right.$, Supplementary Table 1). A total 487 genes over-represented KEYWORDS terms related to polymorphism (false discovery rate, FDR: $P<0.001$ ), representing genomic instability; only four Kyoto Encyclopedia of Genes and Genomes (KEGG) pathways (Table 1), including tight junction, adherens junction, glycosphingolipid biosynthesis, and axon guidance, were significantly enriched (FDR: $P=$ $0.006,0.006,0.023$, and 0.036 , respectively) according to the Database for Annotation Visualization and Integrated Discovery (DAVID) (Supplementary Table 1). The Search Tool for the Retrieval of Interacting Genes (STRING 10.0) predicted physical interaction between STK31 and the PIWI subfamily of Argonaute proteins (PIWIL1, PIWIL3, PIWIL4) and the Tudor family (TDRD5, TDRD7, TDRD9, TDRD15, TDRKH) (Figure 5).

\section{DISCUSSION}

STK31 is highly conserved in humans, chimpanzees, and gorillas. Previous reports have stated that the STK domain is required for regulating cancer cell differentiation [14] and STK expression is often altered in human cancers [17].

The present study demonstrates that, except the testes, STK31 is not expressed in normal tissues but aberrantly expressed in PC tissues, indicating that STK3I is a CT gene in PC. Whether STK31 is expressed is related to the pathologic stage, new neoplasm status, and prognosis of PC, which might be a new means of aiding clinical diagnosis and estimating the degree of severity. As lower STK31 expression is beneficial for patients with PC, perhaps attempts should be made to inhibit the expression of STK31. These inhibitors of STK31 are akin to a molecular therapeutic target, to improve the survival of patients with PC. There are numerous commercially available inhibitors of STKs now including inhibitors of the STK31 STK domain [18].

Currently, there are four major mutation driver genes of PC: KRAS, CDKN2A, TP53, and SMAD4. However, only about two-thirds of patients with PC carry one or more mutations on these genes. We also found that only $2 \%$ of patients with PC carry STK31 mutations. Interestingly, we found that STK31 was activated by demethylation, which is also an important mechanism for 
the reactivation of most $\mathrm{CT}$ genes $[9,19,20]$, which is consistent to Yokoe's study [21].

In the testis, STK31 expression is limited to spermatogonia [22], indicating its key role in germ cell differentiation. However, Fok and his group subsequently found that STK31 could also regulate colon cancer cell differentiation [14]. In this present study, we found that STK31 interacts with the PIWI subfamily (PIWIL1, PIWIL3, PIWIL4), which is confirmed by co-immunoprecipitation assay in vivo and in vitro in mice testes [12]. PIWI subfamily comprised of evolutionarily conserved proteins containing both PAZ and Piwi motifs. It plays an important role in stem cell self-renewal, RNA silencing, and translational regulation. And $S T K 31$ also interacts with the Tudor family (TDRD5, TDRD7, TDRD 9, TDRD15, TDRKH), an evolutionarily conserved family of proteins involved in germ cell development. These two families have long been interrelated. PIWIL1, PIWIL3, and PIWIL4 act as intrinsic regulators of the self-renewal capacity of germ line and hematopoietic stem cells, and are believed to be involved in cancer development [23-26]. TDRD5, $T D R D 9$, and TDRKH are essential for PIWI-interacting RNA (piRNA)-mediated retrotransposon silencing in the male germline [27-29].

In conclusion, STK31 is a CT gene and is reactivated by demethylation. STK31 expression is significantly higher in relapsed patients, or patients with advanced pathologic stage or poorer prognosis, suggesting that STK31 might be of potential clinical value. STK31 interacts with the PIWI and Tudor families, which suggests that it might play a key role in maintaining genomic instability. Molecular targeting treatment has evolved along with better understanding of the mechanisms of cancer, and STK31 may be a good molecular therapeutic target in PC.

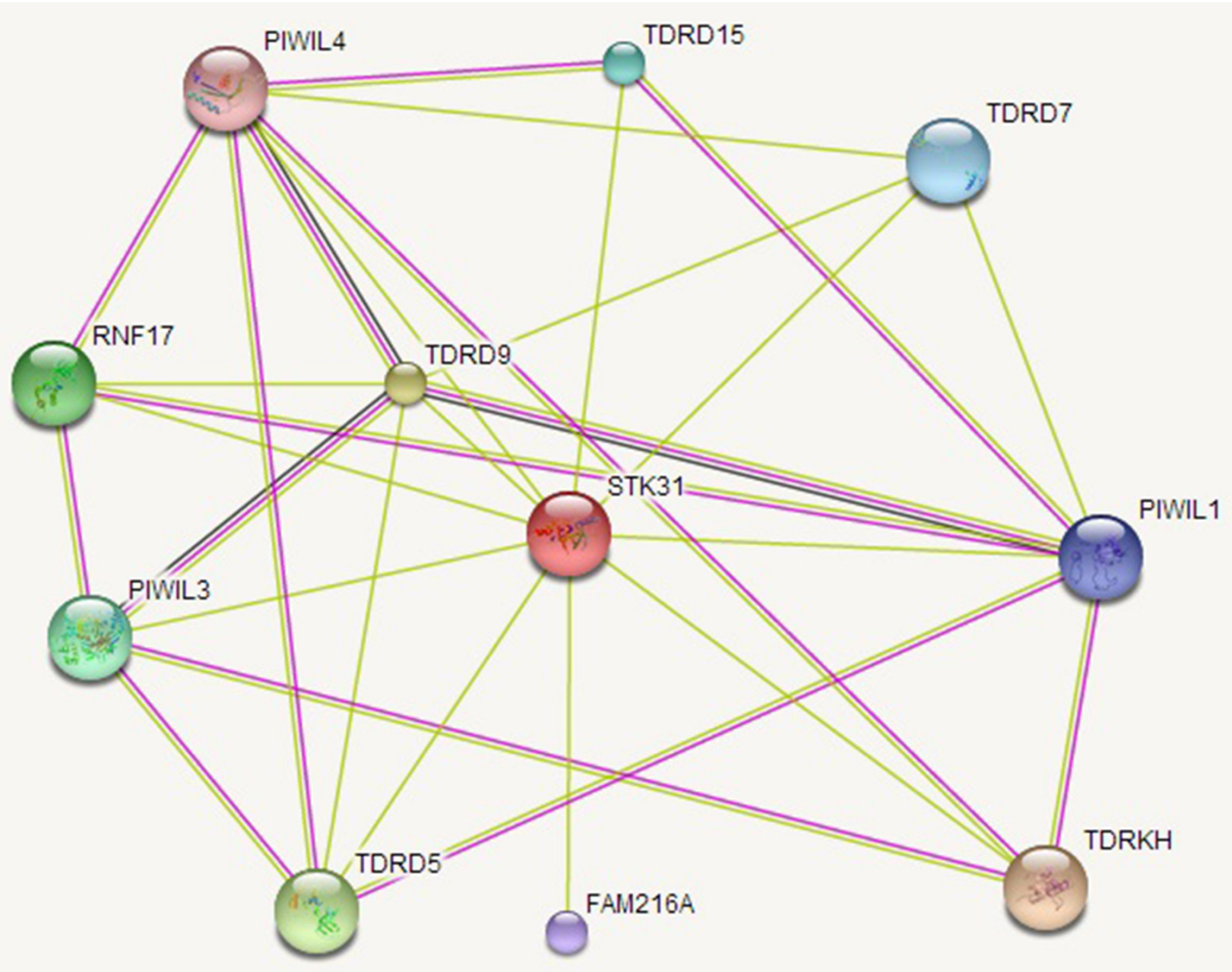

Figure 5: The STK31 gene network. STK31 interacts with the PIWI subfamily of Argonaute proteins (PIWIL1, PIWIL3, PIWIL4) and the Tudor family (TDRD5, TDRD7, TDRD9, TDRD15, TDRKH). 


\section{MATERIALS AND METHODS}

\section{Public datasets}

We used multiple public databases containing data on both normal and PC tissues to evaluate the expression pattern of STK31. The GTEx contains information on gene expression in multiple normal tissues, including the pancreas and testis (http://www.gtexportal.org/home/) [30]. The HPA presents the expression levels of both RNA and protein in normal and tumor tissues (http://www. proteinatlas.org/) [31]. The transcriptional profile and clinical data of PC were obtained from PAAD datasets in TCGA (released on June 1, 2015 https://tcga-data.nci.nih. gov/tcga/tcgaHome2.jsp) [32]. In total, 178 samples had both gene expression and clinical data. Level 3 released gene expression data for RNA-seq was performed RNASeq by Expectation Maximization (RSEM). RSEM is an accurate transcript quantification from RNA-Seq data [33].

\section{STK31 tissue expression pattern}

STK31 expression data were extracted from the above databases and the differential expression levels between clinical statuses were analyzed using the chisquare test. Survival analysis was used to evaluate the prognostic role of STK31 in PC, and log-rank testing was used to determine the significance for Kaplan-Meier analyses to uncover the indication for survival time.

\section{STK31 regulatory mechanism and gene ontology (GO) analysis}

Correlation analysis was performed to establish a relationship between methylation and STK31 expression, which suggested potential regulation of STK31. The role of histone modification in promoter region $(2 \mathrm{~kb}$ upstream of the STK31) to the STK31 was assessed in UCSC genome browser [34]. The relationship of all other genes $(20,531$ genes) with STK31 was assessed in the RNA-seq of TCGA PAAD data, which used the Spearman test and considered genes with Spearman $P<1 \times 10^{-6}$ as STK31-related. The GO analysis was executed by DAVID 6.8 Beta [35], which systematically extracts biological pathways from large gene lists. The Functional_Categories (KEYWORDS) and pathway (KEGG pathway) of the STK31-related genes were analyzed using DAVID with FDR $P<0.05$ (based on the hypergeometric distribution) and count $\geq 2$ (number of genes).

\section{Protein-protein interactions (PPI) network analysis}

The STRING 10.0 [36] database is commonly used to retrieve predicted protein interactions. STRING 10.0 covers a total 2031 organisms and 9,643,763 proteins. All PPI obtained by STRING 10.0 have confidence scores. We searched the STK31-interacting genes, and selected genes with a confidence score $\geq 0.4$ to construct the PPI network.

\section{CONFLICTS OF INTEREST}

All authors have reviewed the final version of the manuscript and approved it for publication. The authors have no conflicts of interest to declare.

\section{GRANT SUPPORT}

This work was supported by grants from the National Natural Science Foundation of China (81672449, $81272239,81672471,81300351)$, Talents planning of six summit fields of Jiangsu Province (WSW-032), the Program for Development of Innovative Research Team in the First Affiliated Hospital of NJMU, Priority Academic Program Development of Jiangsu Higher Education Institutions (PAPD, JX10231801).

\section{REFERENCES}

1. Bilimoria KY, Bentrem DJ, Ko CY, Stewart AK, Winchester DP, Talamonti MS. National failure to operate on early stage pancreatic cancer. Annals of surgery. 2007; 246:173-180.

2. Hidalgo M. Pancreatic cancer. The New England journal of medicine. 2010; 362:1605-1617.

3. Kamisawa T, Wood LD, Itoi T, Takaori K. Pancreatic cancer. Lancet (London, England). 2016; 388:73-85.

4. Iodice S, Gandini S, Maisonneuve P, Lowenfels AB. Tobacco and the risk of pancreatic cancer: a review and meta-analysis. Langenbeck's archives of surgery / Deutsche Gesellschaft fur Chirurgie. 2008; 393:535-545.

5. Raimondi S, Lowenfels AB, Morselli-Labate AM, Maisonneuve P, Pezzilli R. Pancreatic cancer in chronic pancreatitis; aetiology, incidence, and early detection. Best practice \& research Clinical gastroenterology. 2010; 24:349-358.

6. Bosetti C, Rosato V, Li D, Silverman D, Petersen GM, Bracci PM, Neale RE, Muscat J, Anderson K, Gallinger $\mathrm{S}$, Olson SH, Miller AB, Bas Bueno-de-Mesquita $\mathrm{H}$, et al. Diabetes, antidiabetic medications, and pancreatic cancer risk: an analysis from the International Pancreatic Cancer Case-Control Consortium. Annals of oncology : official journal of the European Society for Medical Oncology / ESMO. 2014; 25:2065-2072.

7. Arslan AA, Helzlsouer KJ, Kooperberg C, Shu XO, Steplowski E, Bueno-de-Mesquita HB, Fuchs CS, Gross MD, Jacobs EJ, Lacroix AZ, Petersen GM, Stolzenberg-Solomon RZ, Zheng W, et al. Anthropometric measures, body mass index, and pancreatic cancer: a pooled analysis from the 
Pancreatic Cancer Cohort Consortium (PanScan). Archives of internal medicine. 2010; 170:791-802.

8. Vogelstein B, Papadopoulos N, Velculescu VE, Zhou S, Diaz LA, Jr., Kinzler KW. Cancer genome landscapes. Science (New York, NY). 2013; 339:1546-1558.

9. Simpson AJ, Caballero OL, Jungbluth A, Chen YT, Old LJ. Cancer/testis antigens, gametogenesis and cancer. Nature reviews Cancer. 2005; 5:615-625.

10. Wang C, Gu Y, Zhang K, Xie K, Zhu M, Dai N, Jiang Y, Guo X, Liu M, Dai J, Wu L, Jin G, Ma H, et al. Systematic identification of genes with a cancer-testis expression pattern in 19 cancer types. Nature communications. 2016; 7:10499.

11. Garcia PL, Miller AL, Kreitzburg KM, Council LN, Gamblin TL, Christein JD, Heslin MJ, Arnoletti JP, Richardson JH, Chen D, Hanna CA, Cramer SL, Yang ES, et al. The BET bromodomain inhibitor JQ1 suppresses growth of pancreatic ductal adenocarcinoma in patient-derived xenograft models. Oncogene. 2016; 35:833-845.

12. Bao J, Wang L, Lei J, Hu Y, Liu Y, Shen H, Yan W, Xu C. STK31(TDRD8) is dynamically regulated throughout mouse spermatogenesis and interacts with MIWI protein. Histochemistry and cell biology. 2012; 137:377-389.

13. Wu X, Schmidt JA, Avarbock MR, Tobias JW, Carlson CA, Kolon TF, Ginsberg JP, Brinster RL. Prepubertal human spermatogonia and mouse gonocytes share conserved gene expression of germline stem cell regulatory molecules. Proceedings of the National Academy of Sciences of the United States of America. 2009; 106:21672-21677.

14. Fok KL, Chung CM, Yi SQ, Jiang X, Sun X, Chen H, Chen YC, Kung HF, Tao Q, Diao R, Chan H, Zhang XH, Chung YW, et al. STK31 maintains the undifferentiated state of colon cancer cells. Carcinogenesis. 2012; 33:2044-2053.

15. Grivna ST, Pyhtila B, Lin H. MIWI associates with translational machinery and PIWI-interacting RNAs (piRNAs) in regulating spermatogenesis. Proceedings of the National Academy of Sciences of the United States of America. 2006; 103:13415-13420.

16. Chen C, Jin J, James DA, Adams-Cioaba MA, Park JG, Guo Y, Tenaglia E, Xu C, Gish G, Min J, Pawson T. Mouse Piwi interactome identifies binding mechanism of Tdrkh Tudor domain to arginine methylated Miwi. Proceedings of the National Academy of Sciences of the United States of America. 2009; 106:20336-20341.

17. Capra M, Nuciforo PG, Confalonieri S, Quarto M, Bianchi M, Nebuloni M, Boldorini R, Pallotti F, Viale G, Gishizky ML, Draetta GF, Di Fiore PP. Frequent alterations in the expression of serine/threonine kinases in human cancers. Cancer research. 2006; 66:8147-8154.

18. Scapin G. Structural biology in drug design: selective protein kinase inhibitors. Drug discovery today. 2002; 7:601-611.
19. Fratta E, Coral S, Covre A, Parisi G, Colizzi F, Danielli R, Nicolay HJ, Sigalotti L, Maio M. The biology of cancer testis antigens: putative function, regulation and therapeutic potential. Molecular oncology. 2011; 5:164-182.

20. Zendman AJ, Ruiter DJ, Van Muijen GN. Cancer/testisassociated genes: identification, expression profile, and putative function. Journal of cellular physiology. 2003; 194:272-288.

21. Yokoe T, Tanaka F, Mimori K, Inoue H, Ohmachi T, Kusunoki M, Mori M. Efficient identification of a novel cancer/testis antigen for immunotherapy using three-step microarray analysis. Cancer research. 2008; 68:1074-1082.

22. Wang PJ, McCarrey JR, Yang F, Page DC. An abundance of X-linked genes expressed in spermatogonia. Nature genetics. 2001; 27:422-426.

23. Liu X, Sun Y, Guo J, Ma H, Li J, Dong B, Jin G, Zhang J, Wu J, Meng L, Shou C. Expression of hiwi gene in human gastric cancer was associated with proliferation of cancer cells. International journal of cancer. 2006; 118:1922-1929.

24. Beyret E, Liu N, Lin H. piRNA biogenesis during adult spermatogenesis in mice is independent of the ping-pong mechanism. Cell research. 2012; 22:1429-1439.

25. Navarro A, Tejero R, Vinolas N, Cordeiro A, Marrades RM, Fuster D, Caritg O, Moises J, Munoz C, Molins L, Ramirez J, Monzo M. The significance of PIWI family expression in human lung embryogenesis and non-small cell lung cancer. Oncotarget. 2015; 6:31544-31556. doi: 10.18632/ oncotarget.3003.

26. Taubert H, Wurl P, Greither T, Kappler M, Bache M, Bartel F, Kehlen A, Lautenschlager C, Harris LC, Kaushal D, Fussel S, Meye A, Bohnke A, et al. Stem cell-associated genes are extremely poor prognostic factors for soft-tissue sarcoma patients. Oncogene. 2007; 26:7170-7174.

27. Yabuta Y, Ohta H, Abe T, Kurimoto K, Chuma S, Saitou M. TDRD5 is required for retrotransposon silencing, chromatoid body assembly, and spermiogenesis in mice. The Journal of cell biology. 2011; 192:781-795.

28. Shoji M, Tanaka T, Hosokawa M, Reuter M, Stark A, Kato Y, Kondoh G, Okawa K, Chujo T, Suzuki T, Hata K, Martin SL, Noce T, et al. The TDRD9-MIWI2 complex is essential for piRNA-mediated retrotransposon silencing in the mouse male germline. Developmental cell. 2009; 17:775-787.

29. Saxe JP, Chen M, Zhao H, Lin H. Tdrkh is essential for spermatogenesis and participates in primary piRNA biogenesis in the germline. The EMBO journal. 2013; 32:1869-1885.

30. The Genotype-Tissue Expression (GTEx) project. Nature genetics. 2013; 45:580-585.

31. Uhlen M, Fagerberg L, Hallstrom BM, Lindskog C, Oksvold P, Mardinoglu A, Sivertsson A, Kampf C, Sjostedt E, Asplund A, Olsson I, Edlund K, Lundberg E, et al. Proteomics. Tissue-based map of the human proteome. Science (New York, NY). 2015; 347:1260419. 
32. Weinstein JN, Collisson EA, Mills GB, Shaw KR, Ozenberger BA, Ellrott K, Shmulevich I, Sander C, Stuart JM. The Cancer Genome Atlas Pan-Cancer analysis project. Nature genetics. 2013; 45:1113-1120.

33. Li B, Dewey CN. RSEM: accurate transcript quantification from RNA-Seq data with or without a reference genome. BMC bioinformatics. 2011; 12:323.

34. Karolchik D, Hinrichs AS, Kent WJ. The UCSC Genome Browser. Current protocols in bioinformatics. 2012; Chapter 1:Unit1.4.
35. Huang da W, Sherman BT, Lempicki RA. Systematic and integrative analysis of large gene lists using DAVID bioinformatics resources. Nature protocols. 2009; 4:44-57.

36. Szklarczyk D, Franceschini A, Wyder S, Forslund K, Heller D, Huerta-Cepas J, Simonovic M, Roth A, Santos A, Tsafou KP, Kuhn M, Bork P, Jensen LJ, von Mering C. STRING v10: protein-protein interaction networks, integrated over the tree of life. Nucleic acids research. 2015; 43:D447-452. 